\title{
Evaluation of Employees' Awareness of Environmental Management Systems in Four and Five Star Hotels in Alexandria: A Study Applied to Front Office Department \\ Hend M. El Shafey ${ }^{1}$, Mohamed A. Morsy ${ }^{2,}$ Mohamed S. Gad El Rab ${ }^{2}$ \\ ${ }^{1}$ High Institute of Tourism and Hotel Management - Alexandria City (EGOTH) \\ ${ }^{2}$ Faculty of Tourism and Hotels, Fayoum University
}

\section{Abstract}

Hotel sector has embarked on a course of implementing environmental management practices or a much formal tool called environmental management systems (EMS), an innovation which has been profoundly promoted to offer additional benefits to hotels management, as well as the use of water and energy, which may have undesirable environmental effects if these processes are not properly managed and followed up. This research aims to raise awareness of environmental management systems (EMS) in front office department by assessing the employees' awareness of the environmental management systems, the extent to which the employees apply the sound environmental practices, This research is aim to, the population of the study hotels it must be made to increase the employee's awareness of environmental management systems and application of environmental practices like (waste reduction and energy conservation) and highlighting to importance of the environmental awareness of the employees in first class hotels (four and five stars hotels) in Alexandria. To achieve this objective, the researcher surveyed 150 employees in upscale hotels in Alexandria. Data were analyzed using Statistical Package for Social Science (SPSS 22.

Keywords: Room Division, Front Office Department, Environmental Management systems, Environmental Awareness.

\section{Research Objectives}

This research aims to achieve the following objectives:

1- To shed light importance about environmental awareness of employees in front office department in first class hotels in Alexandria.

2- Evaluate the current situation for employees in front office department in first class hotels in Alexandria of implementing environmental practices.

3- Proposing appropriate solutions and recommendations that will develop and improve the effectiveness of environmental awareness among the employees of the front office department for the application of environmental management systems.

\section{Research importance}

1- Increased awareness of employees in front office department to application of environmental management systems to helps rationalize and reduce cost of environmental resources.

2- Improve image of hotel and increase competitiveness through application of environmental management practices like (waste reduction and energy conservation).

\section{Research hypotheses}

1- There is a relationship of statistical significance between the awareness of employees of environmental management systems and the application of sound environmental practices (waste reduction and energy conservation). 
2- There is a statistically significant relationship between demographic factors of the employees and application environmental practice.

\section{Introduction}

Environmental management system is strategic use of environmental management to hotels to effectively compete with other hotels; it involves long-term activities based on the hotels commitment initiatives Major hotel chains have created operations hotel industry produces an enormous amount of waste and consumes very large amounts of energy, water, and other natural resources (Carmona et al., 2004). Environmental management practice application improvement good image for hotels and increase hotels competitiveness, but their irreversible impact on the environment could be substantial Tourism scholars and industrial professionals have recently advocated an urgent need to adopt greener operations in the hotel industry (Han, 2015). It is attributed to the fact that an increasing number of consumers have embraced the idea of using eco-friendly products and services in the context of lodging operations (Kim and Han, 2010).

This upcoming market has encouraged most if not all leading hotels to timely adopt greener practices to gain a competitive edge. Nevertheless, in order to be successful, a hotel may need to consider barriers hindering the environmental practices (Chan, 2008). Without staff involvement, hotels environmental programs will very likely fail, as many environmental measures are executed by frontline employees (Gurtoo and Tripathy, 2001).

\section{Literature Review}

Tzschentke et al., (2008) refers to the rooms division director is held responsible by the general manager for the efficient and effective leadership and operation of all the rooms' division departments, rooms division sector is composed of departments and functions which play essential roles in providing the services guests expect during a hotel stay (Bardi ,2003). In most hotels the rooms division generates more revenue than other division's. The main source of income for most hotels comes from the rooms division and the food and beverage department. In general, the rooms division comprises two major departments, the front office and housekeeping as is shown in Figure (1), which is involved in the sales or services of rooms to guests. (Powers, 2005) The director of rooms is responsible to the general manager for the effective leadership and smooth operation of all departments that make up the rooms division.

Figure 1: Organization of Rooms Division Sector

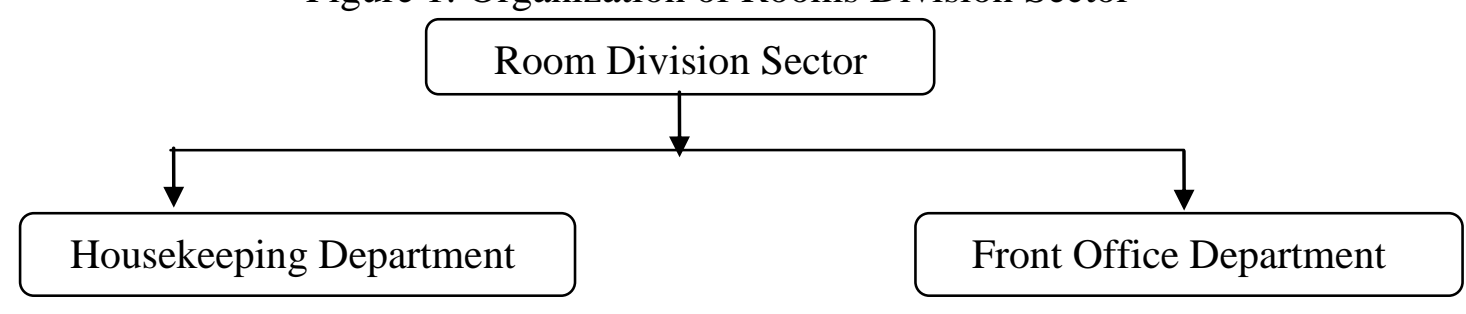

Source: Ivica (2015)

Front office department is one of the most important visible departments of the hotel. The guests contact the front office personnel to answer their questions about the destination, suggest restaurants in the area and so on. It is thus obvious that the hotel relies heavily on its front office personnel in order to convince their guests about the service quality. This in turn will involve several key areas of activity presented below (Bardi, 2007). 
The three main functions of the front office are as follows (Murray and Benny, 2009).

1. Selling rooms.

2. Maintaining balanced guest accounts.

3. Providing services and information to guests.

Jones and Lockwood (2004) describing the front office "a bundle of duties and guest services". These two definitions go some way to outlining the importance of front office plays in the delivery of customer service, as well as ensuring standards are met. The front office team needs to be knowledgeable of both the standards and the SOPs in place, in order for standards to be achieved. In relation to standards, it is the front office team's job to ensure that the customer's first contact with the hotel is a positive experience. It is the job of the front office team to manage the service encounter effectively.

Environmental Management for Hotels Industry

According to (Jaana, 2010) Tourism can be regarded as one of the largest industries in the world as it offers employment for nearly 200 million people. Yearly there are approximately 800 million travelers and the number is expected to be doubled by the year 2020. A huge number of visitors also put enormous stress on the environment.

The hotelier sector has important environmental impacts have been increasing too increasingly in many cases to look for considering and protect the natural environment where if it inserts since this is part of the central "product" that it offers to customers (Pinheiro, 2006).

\section{Defining Environmental Management System}

Tambovceva (2014) added that the Environmental management systems is a transparent, systematic process known organization sectors, with the purpose of prescribing and implementing environmental goals, policies, and responsibilities, as well as regular auditing of its elements. Hotels have also been inspired by increasing environmental consciousness among employees to take actions to reduce the impact of its operations on the environment. Having an environmental management program addresses this. Environmental management is the set of processes and practices introduced and done by an organization for the reduction, prevention and elimination of negative environmental effects arising from its operations (Hsieh, 2012).

An EMS is a component of an organization's overall management system that commonly includes an environmental policy, environmental aspects, objectives, targets, actions, significant aspects, environmental programs, legal requirements, training and awareness, organizational structure, communication, emergency preparedness, operational and document control, plans for addressing nonconformities, management reviews and auditing (Morrow and Rondinelli, 2002).

Reasons for Hotels Implementation in EMS

Rahman et al., (2012) refers that Environmental management in hospitality industry of the hotels sector is receiving priority in this 21 st century environmental conscious human societies worldwide. In their pursuit for good environmental practice, hotels are implementing EMS. Improving a hotelse environmental performance can also help create an environmentally-friendly environment for staff and customers, helps the company gain a competitive advantage and raises the corporate image of the business (Tortella and Tirado, 2011).

Examples of the Process to Achieve the EMS in Front Office Department

- Reduces Waste: According to (Stipanuk, (2002) and Swarbrooke (2007).

- The use of recycled paper for domestic use.

- Use behind the paper used to take some notes. 
- Cancel unwanted correspondence.

- The collection of papers used and stored in the warehouse for recycling.

- Reduce the use of tools and single-use cups and replacing them with tools made of porcelain

- The use of imaging papers duplex.

- The purchase of materials and tools from qualified persons.

- Use pens or containers printers that can 'birth of use and refilling ink.

- Energy Saving:

- The closure of electrical appliances and lights when not in use.

- The use of natural lighting and ventilation whenever possible

- Adjust heat and air conditioning systems at the perfect temperature.

- The use of batteries that can be recharged.

Environmental Awareness

Environmental awareness is essential starting points to take action for dealing with environmental problems in the world. People's environmental awareness and concerns are important concepts to discuss for sustainable life. In the literature, researchers put emphasis on environmental awareness and concerns of people in order to structure better environmental awareness According to Ezel (2012).

Defining Environmental Awareness:

Environmental awareness is defined by (Chan, et al, 2014) as a combination of motivation knowledge and skills. When the environmental awareness of an individual is combined with external stimulating physical and practical conditions, the result can be a desire and will to make environmentally friendly choices.

Environmental Awareness is concern towards environment or environmental problems. In another word it is defined as "an idea holding a general impression or consciousness about something without having to know much about it (Mukesh et al, 2015).

High level of environmental awareness enables conscious choices for acting in an environmentally friendly way. Having resources available may enhance an individual ability to act .on the other hand a lack of resources does not hinder using effective low-cost and no- cost sustainable methods and actions (Paulina, 2006).

According to John et al, (2006) there are two different approaches is available to measure and analyze environmental awareness: one is based on investigating the three basic elements: motivation, knowledge and skills by (interviews, questionnaires and tests) and the other concentrates on measuring concrete environmentally friendly choices, actions and practices (e.g. use of waste recycling facilities, amount of resources that are allocated to environmental matters, etc.)

Ding (2008) According to that environmental awareness influences several spheres of an individual's life- private, working and political. The level of an individual's public environmental awareness afferents the choices in private life professional of exerts an impact on the actions in working life. Political environmental awareness has an influence on voting and political behaviors. Therefore, environmental information has a different target audience:

1- The general public, which is often passive as a recipient.

2- Professionals, who are often motivated to actively seek out the relevant environmental information needed for their work.

3- Politicians, who need information as raw material for their proposals and as abases for their decisions. 


\section{Importance of Environmental Awareness:}

conscious hotel operates all sections business responsibly and challenge for better, is committed to continuous improvement of its environmental awareness and to decreasing negative environmental impacts, And affects the increased environmental awareness of employees (Paulina, 2006). Force hotels to implement environmentally sustainable business practices that require the availability of reliable tools to assess the impact of the hotel on the environment, of which environmental management systems and environmental accounting are emphasized. Environmental responsibility is the duty that a establishments has to operate in a way that protects the environment (Sandra and Dubravka, 2014) .Therefore, an environmentally responsible hotel is the one that carries out activities for reducing its impact on the environment by reducing the consumption of non-renewable natural resources, It is necessary to first discover the barriers that prevent the implementation of environmental practice and then develop to remove the risks, increase environmental awareness, share the best green practices (Beredugo and Mefor, 2012).

\section{Methodology}

This chapter gives the aims of the primary research, outlines the principal research techniques available, the justification for the choice of techniques used, and details, and finally shows the specific questionnaire form answer the study hypotheses.

The purpose of this study is to assess the awareness of the employees of environmental management systems. The objective of the study is that it is necessary to assess the current situation regarding the awareness of workers in environmental management systems and the importance of applying sound environmental practices on the basis that the application of environmental management systems in hotel establishments ensures the preservation of the environment to be healthy for human and employees On the environmental balance and the achievement of the strategic objective of the sustainable environment. Originally the questionnaire was designed in English. The decision was made to translate the research questionnaire into Arabic and to distribute the questionnaire because of the official language in Egypt, to make it very clear for the respondents.

\section{Population and Sample}

The target population in this study is front office Employees in four and five star hotels in Alexandria, which consists of fourteen hotels which was selected randomly, the number of employees representing about (210) employees according to human resource department, while a sample of this study consists of (180) responding which was selected employees randomly; (150) responding was form valid for analysis response rate is $83 \%$.

\section{Research Design:}

Questionnaire design was divided into four main sections, the first one is consists of question about demographic factors of employees in front office department in first class hotels in Alexandria. The second construct is awareness of employees about environmental management system. The three consist is application of waste management practices, finally, the fourth consist is Contain the environmental management practices about Energy Saving, Five-point likert scale of 1-5 was used (1= Strongly Agree, 5= Strongly Not Agree).

Statistical Analysis: 
In the first examination of the data, frequency table and descriptive statistics which include frequency distributions and cross-tabulations were computed and used to summarize data. The collected data have been classified and tabulated to be thoroughly analyzed using Statistical Package for Social Science (SPSS 22). The mean and standard deviation have been calculated to classify the sets and determine how homogenous or discrepant (inconsistent) the sample is, regarding all research variables. Work the schedule of duplicates to know evaluation of employee's awareness of environmental management system and used chi Square test was for a number of questions to determine the effect of a variable on the other. The ANOVA test was used to study the relationship between the characteristics of consciousness and the demographic factors analyze variance and to measure the significance of differences between variables. Cronbach's alpha was used to assess survey reliability. The reliability coefficient was 0.864 , which is considered as acceptable reliability.

\section{Results and Discussion}

After the discussion of the related review, the methods and tools used for conducting this study, before starting this discussion of obtained results from questionnaire, it is important to clarify that the next discussed results gather the results with hotels employees in front office department within the targeted hotels in this study.

Sample Demographics: The first section of the survey asked the respondents to identify their biographical information according to table (1) shows that the total number of respondents on the questionnaire about 150 responding from the total sample selected, According to Question one it asked about gender they represent 80 males by (53.3 percent) 70 females by ( 46.7 percent It is clear that the front office department is more dependent on male employees than females, with 53\% and females at $46 \%$. The male labor force is more labor-intensive and the male labor needs are higher than females. In hotels, it is preferable to place females as it is the first place that the guest deals with immediately after arrival. The reception is welcome and the first impression of the guest is that of the female.

Question two about age they are between 18-30 and the largest percentage, representing (50 percent ) followed age 30-40 representing 65 (43.3 percent) This is a sign many hotels depend on young workers (teenager) because the hotel sector relies heavily on temporary employment because most employees have the desire to leave work for many reasons (Ghanem , 2005) and they represent a large proportion leading to a great vacuum for the hotel ; The total number of responding employees is 130 total sample and represents (86.6 percent) supervisors account for 13 responding, with percentage (8.6 percent) and manager representing (4.6 percent); Respondents were fairly well educated. All respondents held university degrees and more than half of the respondents (86.6 percent); All the surveyed respondents had limited years of work experience less than tow year as representing (52percent); The total sample selected is 65 employee in five-star hotels representing (43.3 percent) and four stars hotels (56.6 percent); All the surveyed respondents of Ownership of sample selected (66 percent) is international chain and Local Chain is (25.3 percent) finally private sector is (8.6 percent) .

Table 1: General Profiles of the Surveyed Hotels

\begin{tabular}{|c|c|c|c|c|c|}
\hline Attribute & \multicolumn{2}{|c|}{$\mathrm{N}=150$} & Attribute & \multicolumn{2}{c|}{$\mathrm{N}=150$} \\
\hline & $\mathrm{N}$ & $\%$ & & $\mathrm{~N}$ & $\%$ \\
\hline Sex : & & & Experience : & & \\
Male & 80 & 53.3 & Less than 2 & 78 & 52 \\
Female & 70 & 46.7 & $2: 5$ & 51 & 34 \\
\hline
\end{tabular}


International Journal of Heritage, Tourism and Hospitality Vol. (12), No. (2/2), September, 2018 By: Faculty of Tourism and Hotels, Fayoum University, Egypt

\begin{tabular}{|c|c|c|c|c|c|}
\hline Age : & & & $5: 10$ & 13 & 8.6 \\
$18<30$ & 75 & 50.0 & More Than 10 & 8 & 5.3 \\
$30<40$ & 65 & 43.3 & Classification : & & \\
$40<50$ & 10 & 6.6 & 4 Stars & 85 & 56.6 \\
More than 50 & 0 & 0 & 5 Stars & 65 & 43.3 \\
\hline Position : & & & Ownership : & & \\
Management & 7 & 4.6 & International Chain & 99 & 66 \\
Supervisor & 13 & 8.6 & Local Chain & 38 & 25.3 \\
Employee & 130 & 86.6 & Private Sector & 13 & 8.6 \\
\hline Education : & & & & & \\
High School & 0 & 0 & & & \\
Education Diploma & 17 & 11.3 & & & \\
University Education & 130 & 86.6 & & & \\
Postgraduate & 3 & 2 & & & \\
\hline
\end{tabular}

Application of Environmental Management Systems:

Table (2) shows that $(41.3 \%)$ of the hotels did not implement environmental management systems and that (34.6\%) implement environmental management systems and that about $(60 \%)$ of the departments of these hotels do not care about raising the environmental awareness of their employees (33.3\%) managers of front office departments in these hotels do not clarify the concept of environmental management of workers and its importance to the hotel as it turned out that by (36.6\%) these hotels do not provide adequate training on environmental management systems and that by $(53.35 \%)$, these training programs are insufficient to increase environmental awareness of working in environmental management systems And that by (33.3\%) these departments do not follow the application of environmental practices by employees inside the hotel and that by (34.6\%) of these departments are updating and developing information on environmental practices and that by (41.3\%) The administrations of these hotels do not care to obtain specialized certificates in the field of environmental management.

Table 2: Frequency, Mean and Std.Dev of the Awareness Characteristic

\begin{tabular}{|c|c|c|c|c|c|c|c|c|c|c|c|c|c|}
\hline \multirow[t]{2}{*}{ Q } & \multirow[t]{2}{*}{$\begin{array}{l}\text { " General Question " } \\
\text { Part One }\end{array}$} & \multicolumn{2}{|c|}{$\begin{array}{l}\text { Strongly } \\
\text { Agree }\end{array}$} & \multicolumn{2}{|c|}{ Agree } & \multicolumn{2}{|c|}{ Neutral } & \multicolumn{2}{|c|}{ Not Agree } & \multicolumn{2}{|c|}{$\begin{array}{c}\text { Strongly } \\
\text { Not Agree }\end{array}$} & \multirow{2}{*}{$\begin{array}{c}\text { Mea } \\
\mathrm{n}\end{array}$} & \multirow{2}{*}{$\begin{array}{l}\text { Std. } \\
\text { Dev }\end{array}$} \\
\hline & & $\mathrm{F}$ & $\%$ & $\mathrm{~F}$ & $\%$ & $\mathrm{~F}$ & $\%$ & $\mathrm{~F}$ & $\%$ & $\mathrm{~F}$ & $\%$ & & \\
\hline 1 & are your hotel applies an EMS & 52 & 34.6 & - & - & 13 & 8.6 & 62 & 41.3 & 23 & 15.3 & 1.6 & .62 \\
\hline 2 & $\begin{array}{l}\text { environmental awareness of the } \\
\text { hotel staff }\end{array}$ & 40 & 26.6 & 17 & 11.3 & 3 & 2 & 45 & 30 & 45 & 30 & $\begin{array}{c}1.3 \\
8\end{array}$ & .61 \\
\hline 3 & $\begin{array}{l}\text { The front office manager } \\
\text { explains the E.M employees } \\
\text { department }\end{array}$ & 38 & 25.3 & 20 & 13.3 & 5 & 3.3 & 50 & 33.3 & 37 & 25 & $\begin{array}{c}2.5 \\
9\end{array}$ & $\begin{array}{c}1.1 \\
2\end{array}$ \\
\hline 4 & $\begin{array}{l}\text { training programs } \\
\text { environmental management } \\
\text { system }\end{array}$ & 30 & 20 & 23 & 15.3 & 5 & 3.3 & 37 & 25 & 55 & 36.6 & $\begin{array}{c}1.8 \\
1\end{array}$ & .78 \\
\hline 5 & $\begin{array}{l}\text { The training programs provided } \\
\text { are sufficient employees }\end{array}$ & 27 & 18 & 23 & 15.3 & 7 & 4.6 & 40 & 26.6 & 53 & 35.3 & $\begin{array}{c}1.7 \\
6\end{array}$ & .91 \\
\hline 6 & $\begin{array}{l}\text { The manager how to applying } \\
\text { EMS To employee in hotel }\end{array}$ & 37 & 24.6 & 50 & 33.3 & 13 & 8.6 & 25 & 16.6 & 25 & 16.6 & $\begin{array}{c}2.7 \\
4 \\
\end{array}$ & $\begin{array}{c}1.1 \\
3\end{array}$ \\
\hline 7 & $\begin{array}{l}\text { raising the environmental } \\
\text { awareness of the employees }\end{array}$ & 35 & 23.3 & 52 & 34.6 & 10 & 6.6 & 23 & 15.3 & 30 & 20 & $\begin{array}{c}1.4 \\
7\end{array}$ & .64 \\
\hline 8 & $\begin{array}{l}\text { certificates environmental } \\
\text { management }\end{array}$ & 52 & 34.6 & 13 & 8.6 & - & - & 62 & 41.3 & 23 & 15.3 & $\begin{array}{c}2.7 \\
6\end{array}$ & $\begin{array}{c}1.1 \\
9\end{array}$ \\
\hline
\end{tabular}


4.2 The Awareness of Front Office department about environmental management system and Demographic Factors of employees:

The ANOVA test was used to study the relationship between the characteristics of awareness and the demographic factors show that in table (3): The correlation between the characteristics of awareness among workers and between sex and gender shows that there is no correlation between male and female employees who perform the same functions and responsibilities and receive the same training courses.

It was also found in the study of the relationship between the characteristics of awareness among workers and between (age) and (job) that there is no correlation relationship According to the study of the sample of the front office staff in terms of educational level, it turns out that the department depends on the holders of bachelor's or licensure. This is due to the requirements of appointment in the department and the department always needs high qualifications and languages and shows that there is no relationship between the characteristics of awareness and the educational level of the employees.

In the study of the relationship between the characteristics of awareness and the years of experience of the workers, it was found that there is no relationship. This is because most hotels depend on temporary employment and they always have the problem of non-employment. To be given training courses to implement sound environmental practices In the study of the relationship between the characteristics of consciousness and the degree of hotel, it was found that there is a strong correlation between the characteristics of awareness and the degree of the hotel at a significant level 0.00 This indicates that the higher the degree of the hotel increased the environmental awareness of employees in the front office, He has increased his interest with the workers by increasing the number of training courses and taking care to apply sound environmental practices.

As shown in the study of the relationship between the characteristics of awareness and (ownership of hotels) it was found that there is a strong correlation between the characteristics of the awareness and the type of ownership of the hotel at a significant level 00. 0 This means that the more the type of ownership of the hotel that follows a global series, This is due to the fact that hotels belonging to international chains have their own standards and environmental practices, which are always applied and obtained environmental certificates with emphasis and control on the application of these standards and practices.

Table 3: ANOVA Test Between characteristics of awareness and demographic factors

\begin{tabular}{|c|c|c|c|c|c|c|}
\hline & & Sum of Squares & df & Mean Square & $\mathrm{F}$ & Sig. \\
\hline \multirow{3}{*}{ Sex } & Between Groups & 4.719 & 24 & .197 & .674 & .843 \\
\hline & Within Groups & 10.214 & 35 & .292 & & \\
\hline & Total & 14.933 & 59 & & & \\
\hline \multirow{3}{*}{ Age } & Between Groups & 7.286 & 24 & .304 & .614 & .893 \\
\hline & Within Groups & 17.298 & 35 & .494 & & \\
\hline & Total & 24.583 & 59 & & & \\
\hline \multirow{3}{*}{ Job } & Between Groups & 7.608 & 24 & .317 & .722 & .796 \\
\hline & Within Groups & 15.375 & 35 & .439 & & \\
\hline & Total & 22.983 & 59 & & & \\
\hline \multirow{3}{*}{$\begin{array}{l}\text { Educat } \\
\text { ion }\end{array}$} & Between Groups & 5.001 & 24 & .208 & 1.140 & .355 \\
\hline & Within Groups & 6.399 & 35 & .183 & & \\
\hline & Total & 11.400 & 59 & & & \\
\hline \multirow{3}{*}{$\begin{array}{l}\text { Experi } \\
\text { ence }\end{array}$} & Between Groups & 25.446 & 24 & 1.060 & 1.756 & .063 \\
\hline & Within Groups & 21.137 & 35 & .604 & & \\
\hline & Total & 46.583 & 59 & & & \\
\hline
\end{tabular}


International Journal of Heritage, Tourism and Hospitality Vol. (12), No. (2/2), September, 2018 By: Faculty of Tourism and Hotels, Fayoum University, Egypt

\begin{tabular}{|c|c|c|c|c|c|c|}
\hline \multirow{3}{*}{$\begin{array}{c}\text { star of } \\
\text { hotel }\end{array}$} & Between Groups & 12.350 & 24 & .515 & 9.824 & .000 \\
\cline { 2 - 7 } & Within Groups & 1.833 & 35 & .052 & & \\
\cline { 2 - 7 } & Total & 14.183 & 59 & & & \\
\hline \multirow{2}{*}{$\begin{array}{c}\text { Propert } \\
\text { y Type }\end{array}$} & Between Groups & 32.225 & 24 & 1.343 & 13.924 & .000 \\
\cline { 2 - 7 } & Within Groups & 3.375 & 35 & .096 & & \\
\cline { 2 - 7 } & Total & 35.600 & 59 & & & \\
\hline
\end{tabular}

\section{Waste Management in the Front Office Department}

Table (4) shows that about $64 \%$ of the hotels use the recycled paper again and $57.9 \%$ use the back of the paper to write and print on both sides, and that about 48.6 use the paper in the confirmed correspondence only and that by 57.9 they reduce the use Tools and cups with one use and that by $42 \%$ do not use pens and printers that can be reused or refilled again and by 61.9 they collect the paper used and saved for recycling.

Table 4: Frequency, Mean and Std.Dev of the Wast Management

\begin{tabular}{|c|c|c|c|c|c|c|c|c|c|c|c|c|c|}
\hline \multirow[t]{2}{*}{$\mathrm{Q}$} & $\begin{array}{l}\text { " General Questions " } \\
\text { Part Two }\end{array}$ & \multicolumn{2}{|c|}{$\begin{array}{l}\text { Strongly } \\
\text { Agree }\end{array}$} & \multicolumn{2}{|c|}{ Agree } & \multicolumn{2}{|c|}{ Neutral } & \multicolumn{2}{|c|}{ Not Agree } & \multicolumn{2}{|c|}{$\begin{array}{l}\text { Strongly } \\
\text { Not Agree }\end{array}$} & \multirow{2}{*}{ Mean } & \multirow{2}{*}{$\begin{array}{c}\text { Std.D } \\
\text { ev }\end{array}$} \\
\hline & Waste Management & $\mathrm{F}$ & $\%$ & $\mathrm{~F}$ & $\%$ & $\mathrm{~F}$ & $\%$ & $\mathrm{~F}$ & $\%$ & $\mathrm{~F}$ & $\%$ & & \\
\hline 1 & $\begin{array}{l}\text { Use Recycled Paper for local } \\
\text { Use. }\end{array}$ & 32 & 22 & 58 & 38 & - & - & 52 & 35 & 8 & 5 & 3.36 & 1.30 \\
\hline 2 & $\begin{array}{l}\text { Use the back of the paper to write } \\
\text { notes or data double-sided } \\
\text { printing }\end{array}$ & 62 & 41 & 25 & 17 & 7 & 5 & 35 & 23 & 21 & 14 & 2.65 & 1.17 \\
\hline 3 & $\begin{array}{l}\text { Use of paper in confirmed } \\
\text { correspondence only }\end{array}$ & 10 & 7 & 22 & 15 & 23 & 15 & 68 & 45 & 27 & 18 & 2.46 & 1.12 \\
\hline 4 & $\begin{array}{l}\text { Minimize the use of disposable } \\
\text { tools and cups }\end{array}$ & 28 & 18 & 55 & 37 & 10 & 7 & 35 & 23 & 22 & 15 & 3.20 & 1.38 \\
\hline 5 & $\begin{array}{l}\text { Using inkjet cartridges that can be } \\
\text { reused or refilled with ink }\end{array}$ & 27 & 18 & 35 & 23 & 8 & 5 & 50 & 34 & 30 & 20 & 2.86 & 1.12 \\
\hline 6 & $\begin{array}{l}\text { Collect used paper and save them } \\
\text { for recycling }\end{array}$ & 8 & 5 & 32 & 22 & - & - & 83 & 55 & 27 & 18 & 2.40 & 1.16 \\
\hline \multicolumn{12}{|c|}{ Total } & 16.93 & 7.25 \\
\hline \multicolumn{12}{|c|}{ Total Mean } & 2.82 & 1.20 \\
\hline
\end{tabular}

The data in Table (4) show that when the employees in the front office of the hotels were asked about the use of recycled paper in local use, the percentage of (Agree) was $38 \%$ and (Strongly Agree) was $22 \%$. The mean it was 3.36 and the standard deviation was 1.30 . The results show that the total agrees rate has reached $60 \%$ on the use of recycled paper for local use. This result may be due to the interest in the management of these hotels in matters related to environmental management, which include reducing the quantities of waste produced by hotels. This is indicated by (Trung and Kumar , 2005) who mentioned the importance of reducing the waste generated from the hotel and its amounts through which hotels can reduce operating costs and depreciation and thus increase operating profit for the hotel.

The second questions if they use the back of the paper to writing notes or data and double-sided printing, the rate of (Agree) has reached 17\% and (Strongly Agree) was $41 \%$ and the direction of the mean to the approval of 2.65 and the standard deviation of 1.17. When discussing the data, we found that the approval rate was $58 \%$ on the use of the back of the paper in writing notes or double-sided printing this result is due to the fact that the application of this practice through the view of the management of these hotels that it does not require any effort or cost material, but vice versa. This is confirmed by (Alexandr, 2002) where he stressed the importance of reducing and 
treatment of waste and that by reducing the amount of waste, it will also reduce the cost of purchase, and residues resulting from the hotel.

when asked the front office staff in the hotels population study on the use of paper in the confirmed correspondence only, the percentage of ( Not Agree ) was $45 \%$ and the percentage of (Strongly Not Agree) 18\% and the trend of the mean to the lack of approval was 2.46 and the standard deviation 1.15 . The application of this practice requires a great awareness of the employees to apply the rule be aware that the use of one sheet without confirmation or necessity will increase the waste generated from the section.

It is clear from Table (4) that when the staff was asked to reduce the use of single-use tools and cups, the percentage of (Agree) was 37\%, the (Strongly Agree) was 18\%, the mean direction was 3.20 and the standard deviation is 1.38. This is due to the awareness of these hotels about the importance of applying sound environmental practices and the importance of reducing the waste generated by the department. For the employees, they reduce the tools and cups of one use as it is the policy of the Administration this is contrary to what (Sandra and Dubravka ,2014) pointed out the importance of reducing the quantities of waste and this will be done by limiting the use of tools that cannot be returned. Use it again as well as use a few packaging materials.

According to the data shows that when the employees of the department are asked about the use of Reusable and refillable ink pens and printers refills the percentage of (Not Agree) was 34\% and (Strongly Not Agree) was 20\%. the mean was 2.86 and the standard deviation was 1.45 , The importance of the application of sound environmental practices and the importance of reducing the amount of waste generated by the section using printer cartridges that can be re-used as seen the by administrations of these hotels that the purchase of this type of pens and packages of printers is a little expensive and no need for the cost of the hotel this material cost is unnecessary from their point of view, without regard to the benefits that will accrue to the hotel and the environment from the use of these containers, printers and pens. This is contrary to what was confirmed by Baker (2005), stressing the importance of reducing waste by using products and tools that can be used again.

When employees asked about the collection and storage of the used paper for recycling, the percentage for (Not Agree) was 55\%, and (Strongly Not Agree) was $18 \%$. The mean of was 2.40 and the standard deviation was 1.16 . This result is due to the lack of awareness of the administrations of these hotels regarding the importance of applying some sound environmental practices, including the collection and preservation of paper for recycling. These administrations believe that this practice needs time and effort to implement, which is not available, This is contrary to what was confirmed by (Eldief and Font,2010), where he stressed the importance of collecting and sorting waste from hotels to benefit from recycling again.

Energy Management in the Front Office Department:

It is clear from Table (5) that about $65 \%$ of hotels shut down equipment and lamps when not in use, and that 53.3 use natural lighting and ventilation, 64\% adjust the air conditioning at ideal temperature and $62 \%$ do not use energy saving devices and lamps and that about $80 \%$ make sure that the doors of the hotel are closed tightly in case of central air conditioning. 
International Journal of Heritage, Tourism and Hospitality Vol. (12), No. (2/2), September, 2018

By: Faculty of Tourism and Hotels, Fayoum University, Egypt

Table 5: Frequency, Mean and Std.Dev of the West Management

\begin{tabular}{|c|c|c|c|c|c|c|c|c|c|c|c|c|c|}
\hline \multirow[t]{2}{*}{$\mathrm{Q}$} & \multirow{2}{*}{$\begin{array}{l}\text { " General Questions " } \\
\text { Part three } \\
\text { Energy Management } \\
\end{array}$} & \multicolumn{2}{|c|}{$\begin{array}{c}\text { Strongly } \\
\text { Agree }\end{array}$} & \multicolumn{2}{|c|}{ Agree } & \multicolumn{2}{|c|}{ Neutral } & \multicolumn{2}{|c|}{ Not Agree } & \multicolumn{2}{|c|}{$\begin{array}{l}\text { Strongly } \\
\text { Not Agree }\end{array}$} & \multirow{2}{*}{$\begin{array}{l}\text { Mea } \\
\mathrm{n}\end{array}$} & \multirow{2}{*}{$\begin{array}{l}\text { Std.D } \\
\text { ev }\end{array}$} \\
\hline & & $\mathrm{F}$ & $\%$ & $\mathrm{~F}$ & $\%$ & $\mathrm{~F}$ & $\%$ & $\mathrm{~F}$ & $\%$ & $\mathrm{~F}$ & $\%$ & & \\
\hline 1 & $\begin{array}{l}\text { Shut off appliances and lamps } \\
\text { if not in use }\end{array}$ & 42 & 28 & 58 & 39 & - & - & 30 & 20 & 20 & 13 & 3.48 & 1.43 \\
\hline 2 & $\begin{array}{l}\text { Light and natural ventilation } \\
\text { are used whenever possible }\end{array}$ & 18 & 12 & 27 & 18 & - & - & 58 & 39 & 47 & 31 & 2.40 & 1.40 \\
\hline 3 & $\begin{array}{l}\text { The air conditioners are } \\
\text { adjusted to an ideal } \\
\text { temperature }\end{array}$ & 50 & 33 & 60 & 41 & 5 & 3 & 23 & 15 & 12 & 8 & 3.75 & 1.29 \\
\hline 4 & $\begin{array}{l}\text { Rechargeable batteries are } \\
\text { used }\end{array}$ & 5 & 3 & 23 & 15 & 18 & 12 & 60 & 41 & 44 & 29 & 2.21 & 1.13 \\
\hline 5 & $\begin{array}{l}\text { Energy saving appliances and } \\
\text { lamps are used }\end{array}$ & 58 & 40 & 47 & 30 & 12 & 8 & 18 & 12 & 15 & 10 & 3.76 & 1.34 \\
\hline 6 & $\begin{array}{l}\text { Make sure that the doors of } \\
\text { the hotel are firmly closed in } \\
\text { case of central air } \\
\text { conditioning }\end{array}$ & 68 & 45 & 60 & 40 & 7 & 5 & 15 & 10 & - & - & 4.20 & .93 \\
\hline & Total & & & & & & & & & & & $\begin{array}{c}19.8 \\
0\end{array}$ & 7.52 \\
\hline & Total Mean & & & & & & & & & & & 3.30 & 1.25 \\
\hline
\end{tabular}

Table (5) shows that when asked the front office employees In population study hotels on the turning off devices and lamps in the case of non-use, has reached the( Agree ) rate of $39 \%$ and the (Strongly Agree) was percentage 28\%. The mean trend towards approval was 3.48 and the standard deviation 1.43. When discussing the data, we found out that the approval rate reached $67 \%$, when the equipment and lamps are turned off when used. The result is that the management of these hotels applies this practice as an energy saving for the hotel. It saves the hotel's physical expenses and does not apply this practice as a good environmental practice. This is contrary to what was mentioned by, (mukesh et al, 2015) that Energy saving in the hotel and in the buildings inside the hotel is useful for employees to educate customers and, to increase the environmental awareness they have

Table (5) shows that when the employees of the department are asked about the use of day Light and natural ventilation whenever possible, the percentage of (Not Agree) was 39\% and the percentage of (Strongly Not Agree) was 31\% and the trend of the mean to the not agree of 2.40 and the standard deviation is 1.40, when discussing the data, the total disapproval rate reached $70 \%$ on the use of, Daylight and natural ventilation whenever possible. The result is that the management of these hotels of course prefers to apply this practice on the basis that it will save a lot of money for the hotel. This is contrary to what was said by (Liu and Cruz, 2012) that the most important customers are aware of the environmentally friendly practices and that hotels can profit from customers with high environmental awareness.

The results when asked about the study population that the adjustment of the air conditioners at an ideal temperature show that, the percentage of (Agree) was $41 \%$ and the rate of (Strongly Not Agree) it was 33\%, and the direction of the mean to the approval of 3.75 and the standard deviation 1.29, on discussion the data, the total approval rate was 74\%. air conditioning was adjusted to an ideal temperature. The result is that the hotels' administrations implement this practice in order to save the material cost of the hotel without considering the importance of energy conservation, as well as for employees who carry out the instructions of the hotel management without being aware of the importance of reducing and preserving energy. 
The question of the use of batteries that can be recharged again show that, the percentage of (Not Agree) was $41 \%$ and the (Strongly Not Agree) was 29\%. The mean was 2.21 and the standard deviation was 1.13. In the discussion of the data, we found out that the total rate of disapproval has reached $70 \%$ on the use of rechargeable batteries and the result is that the management of these hotels sees that the purchase of this type of batteries is expensive for the hotel and there is no need to buy or use them. This resulted from their lack of awareness of the importance of applying sound environmental practices, including energy conservation and waste reduction, through the use of batteries that can be recharged.

Table (5) shows that when asked about the use of energy saving devices and lamps .the rate of (Agree) was 30\% and the percentage of the (Strongly Agree) was 40\% with the trend of the mean to 3.76 and the standard deviation of 1.34 In the discussion of the data, we found out that the total approval rate of $70 \%$ on the use of energysaving devices and lamps and this resulted in that the management of these hotels see that if the use of energy-saving devices and lamps will be expensive for the hotel but they will recover the cost than from saving in energy consumption and thus saving in expenses, which was pointed out by (mcleish, 2007) where he pointed out the importance of switching light bulbs to other energy-saving types as they provide 10 to $25 \%$ of less energy.

Finally, the assurance of the closure of the doors of the hotel tightly in the case of operating of central air conditioning show that rate of (Agree) has reached $40 \%$ and the percentage of (Strongly Agree) was $45 \%$ the mean trend towards approval was 4.20 and the standard deviation was. 935 In the discussion of the data, we found out that the total approval rate reached $85 \%$, but it is confirmed that the doors of the hotel closed tightly in the case of operating of central air conditioning and this result in that the administrations of these hotels apply this practice in order to save the cost of the hotel without considering the conservation of energy as a good environmental practices as well as hotel staff implement hotel management instructions without being aware of the importance of conserving energy and reducing consumption.

The correlation coefficient was used to test the significance of the relationship between the hotel applying an environmental management system and awareness of the implementation of environmental practices show that in the table (6) and it was found that there was a strong relationship between them at a significant level of(.000).

Table 6: Regression coefficient with y2 with y3

\begin{tabular}{|c|c|c|c|c|c|c|c|c|}
\hline \multicolumn{2}{|c|}{ Model } & $\mathrm{R}$ & $\mathrm{N}$ & Std.R & Mean & B & $\mathrm{T}$ & Sgn.** \\
\hline \multirow[t]{2}{*}{1} & Y2 & \multirow{2}{*}{$.795^{\mathrm{a}}$} & \multirow[t]{2}{*}{150} & .018 & \multirow[t]{2}{*}{94.575} & .795 & 8.416 & . 000 \\
\hline & Y3 & & & .031 & & .652 & 6.543 & .000 \\
\hline
\end{tabular}

The correlation coefficient was also used to test the significance of the relationship between the hotel applying an environmental management system and the awareness of applying the environmental practices. A strong relationship was found between them at a significant level of (.000).

\section{Recommendations}

This research study adopted a descriptive survey approach to investigate the current state of environmental management and evaluation of employee's awareness in front office management in first class hotels in Alex. To date there has been limited research directed towards environmental management practices, this study provides some interesting results which can be explored further to gain a better understanding of current practice and perceptions of hotel employees about EMS implementation in 
front office management ,Hotel management should pay attention to raise the environmental awareness of the employees in front office department by increasing the number of training courses for employees, and should inform all employees of the department on the rationalization of energy consumption and waste by placing posters and small signs to remind employees, hotel management should follow the application of environmental practices carried out by employees and record their observations he administrations of these hotels shall be concerned with raising the environmental awareness of the employees by developing and updating information on sound environmental practices. Theoretically, results of this study can be made use of in conducting more detailed studies on EMS implementation, not only in hotels but also other industrial service sectors.

\section{References}

Alexander, S. (2002) "Green hotels: Opportunities and resources for success". Zero Waste Alliance, 2-9.

Bardi, J.A. (2007). "Hotel Front Office Management". (4rd Ed). New Jersey: Wiley, p 338.

Beredugo, S.B., Mefor, I.P. (2012), "The Impact of Environmental accounting and Reporting on Sustainable Development in Nigeria", Research Journal of Finance and Accounting, Vol. 3, No. 7, pp. 55-63.

Carmona-Moreno, E., Céspedes-Lorente, J. and De Burgos-Jiménez, J. (2004), "Environmental strategies in Spanish hotels: contextual factors and performance", Service Industries Journal, Vol. 24 No. 3, pp. 101-130.

Chan, E. S. W. (2008)." Barriers to EMS in the hotel industry". International Journal of Hospitality Management, 27(2), 187-196.

Chan, E. S. W., Hon, A. H. Y., Chan, W., \& Okumus, F. (2014). "What Drives Employees' Intentions to Implement Green Practices in Hotels?" The role of knowledge, awareness, concern and ecological behavior. International Journal of Hospitality Management, 40, 2028.

Ding, g. ( 2008 ) " sustainable construction - the role of environmental assessment tools " , journal of environmental management , feb , vol 86 , no . (3), pp. 451 464.

El Dief, M. and Font, X. (2010), " Green marketing practices in Red Sea Hotel Sector in Egypt", Journal of sustainable tourism, 18(2) 157-174.

Ezel,Tekin.,(2012)." Environmental Awareness and Concerns of Service Teachers in a Private Non Profit University". A Master Thesis. The Program of Curriculum and Instruction Bilkent University Ankara.

Han, H. (2015). "Travelers' pro-environmental behavior in a green lodging context": Converging value-belief-norm theory and the theory of planned behavior. Tourism Management, 47, 164177.

Hsieh, Y.-C. (. (2012). "Hotel companies' environmental policies and practices": a content analysis of their web pages. International Journal of Contemporary Hospitality Management, 24 (1), 97-121.

Ivica.B., (2015), "The Role and Importance of Internet Marketing in Modern Hotel Industry" (JPMNT) Journal of Process Management-New Technologies, InternationalVol.3, No.3, pp.34-51.

Jaana ,R. (2010) "Increasing Environmental Awareness of Hotel Customers, Case: a Turkish Eco Hotels, Saimaa University of Applied Sciences, Imatra Unit of Tourism, and Degree Programmed in Tourism Bachelor's Thesis 2010. 
John, F. Duffy, M. Raymond, P. and Genvi ,.(2006)"Improving Environmental Awareness Training in Business" Journal of Cleaner Production, Volume14,Issues6-7,pp.551-562.

Kim, Y., \& Han, H. (2010)." Intention to pay conventional-hotel prices at a green hotel a modification of the theory of planned behavior". Journal of Sustainable Tourism, 18(8), 9971014.

Liu, Z. Anderson, T.; and Cruz, J. (2012). "Consumer Environmental Awareness and Competition in Two Stage Supply Chains". European Journal of Operational Research, 218, 602-613.

McLeish, B. (2007). "Pairing Green Design with Energy Purchasing Strategies": Hospitality . construction, 2(6): 52-54.

Morrow, D., \& Rondinelli, D. (2002). "Adopting Corporate Environmental Management Systems: Motivations and Results of ISO 14001 and EMAS Certification". European Management Journal, 20 (2), 159-171.

Mukesh, K. Panth, P.and Verma, M,. (2015)." The Role of Attitude in Environmental Awareness of Under Graduate Students".International Journal of Research in Humanities and Social Studies.Volume 2, Issue 7, July 2015, PP 55-62.

Murray, M and Benny, C. (2009) "Tourism and Hospitality Studies Introduction to Hospitality"- Manual on Module Introduction to Hospitality he Government of the Hong Kong Special Administrative Region

Paulina, b. (2006) "Environmental Awareness and Initiatives the Swedish and Polish Hotel Industries" Survey Results International Journal of Hospitality Management volune issue 4, December, pp : 662, 682.

Pinheiro,M.D. (2006). "Ambient Construed Sustainable". (Institute for Ambient).

Rahman, I., Reynolds, D. and Svaren, S. (2012). "How 'green' are North American hotels?" An exploration of low-cost adoption practices. International Journal of Hospitality Management, 31, 720-727.

Sandra, J. Dubravka, K. (2014)," Environmental Accounting as Perspective for Hotel Sustainability: Literature Review". Tourism and Hospitality Management, Vol. 20, No. 1, pp. 103-120.

Stipanuk, D. M. (2002). "Hospitality facilities management and design. Lansing", MI: Educational Institute of the American Hotel \& Lodging Association

Swarbrooke, J., \& Homer, S. (2007). "Consumer behavior in tourism". Oxford: Elsevier.

Tortella, B.D. and Tirado, D. (2011). "Hotel water consumption at a seasonal mass tourist destination". The case of the island of Mallorca. Journal of Environmental Management, 1-12.

Trung, D. N., \& Kumar, S. (2005), "Resource use and waste management in Vietnam hotel industry" , Journal of Cleaner Production, 13, 109-116.

Tzschentke, N. A., Kirk, D., \& Lynch, P. A. (2008). Going green: Decisional factors in small hospitality operations. International Journal of Hospitality Management, 27(1), 126-133. 